\title{
ПОИСК СПОСОБОВ РЕШЕНИЯ ПРОБЛЕМ ПЕРЕРАБОТКИ ОТХОДОВ: БИОРАЗЛАГАЕМЫЕ МАТЕРИАЛЫ ИЗ КОНОПЛИ
}

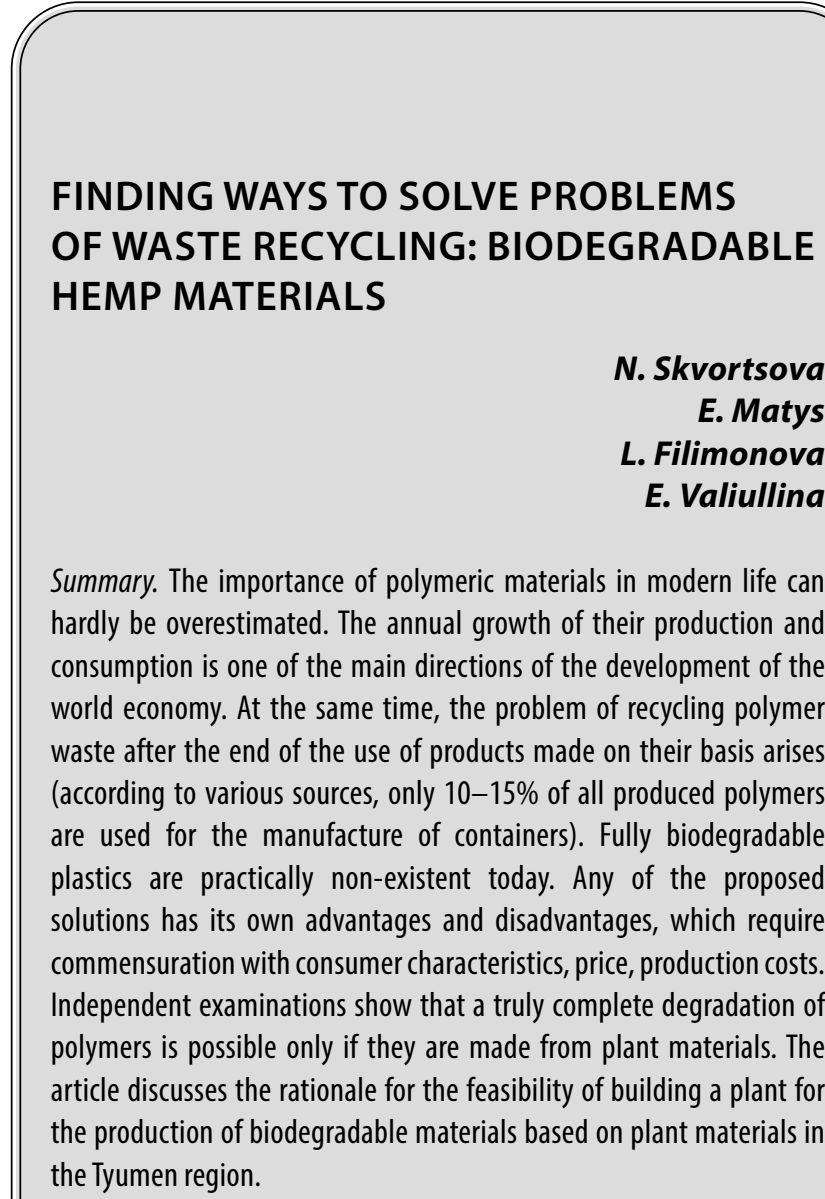

Keywords: biodegradable materials, polymeric materials, hemp production, cultivation of technical hemp, government support, competitive environment, technological process.

\author{
Скворцова Надежда Константиновна \\ Д.э.н., профессор, Тюменский индустриальный \\ университет \\ skvortsovank@tyuiu.ru \\ Матыс Елена Геннадьевна \\ К.э.н., дочент, Тюменский индустриальный \\ университет \\ matyseg@tyuiu.ru \\ Филимонова Лариса Акрамовна \\ К.э.н., дочент, Тюменский индустриальный \\ университет \\ filimonovala@tyuiu.ru \\ Валиуллина Елена Робертовна \\ Тюменский индустриальный университет \\ valiullina.lena@inbox.ru
}

Аннотация. Значение полимерных материалов в современной жизни сложно переоценить. Ежегодный рост их производства и потребления это одно из основных направлений развития мировой экономики. Вместе с тем остро встает проблема утилизации полимерных отходов по истечении использования изделий, изготавливаемых на их основе (по различным источникам только на изготовление тары используется 10-15\% всех производимых полимеров). Полностью биоразлагаемых пластиков на сегодняшний день практически не существует. Любое из предлагаемых решений имеет свои преимущества и недостатки, требующие соизмерения с потребительскими характеристиками, ценой, затратами на производство. Независимые экспертизы свидетельствуют о том, что действительно полное разложение полимеров возможно только в случае их изготовления из растительного сырья. В статье, рассматривается обоснование целесообразности строительства завода по производству биоразлагаемых материалов на основе растительного сырья на территории Тюменской области.

Ключевые слова: биоразлагаемые материалы, полимерные материалы, конопляное производство, выращивание технической конопли, государственная поддержка, конкурентная среда, технологический процесс.

де; для разложения ему необходимы определенные условия окружающей среды; не подлежит повторной переработке; производство его ведет к росту капитальных вложений; побочным продуктом его разложения является метан; и, в конечном, итоге, он не решает проблему загрязнения окружающей среды. По данным ассоциации «Чистая страна», в РФ каждый житель ежегодно производит 400-500 кг бытовых отходов [1]. Кроме того, с течением времени происходит снижение запасов нефти и газа, ведущие к постепенному росту их себестоимости. Именно поэтому, необходимость уси- 
ления надзора над процессом утилизации и разработки новых методов переработки, захоронения и очистки отходов, обусловлена возможностью предотвращения многих экологических катастроф и сохранения планеты для потомков.

Большая значимость исследований в сфере производства продукции из экологически чистого сырья подтверждается всемирной тенденцией перехода к биоразлагаемым материалам, разработкой и совершенствованием инновационных материалов и технологий производства, для решения проблем экологии. При этом, биоразлагаемыми могут быть не только пластиковые материалы, но и, материалы на основе растительного сырья, в том числе, из конопляного волокна. Выращивание технической конопли может стать одним из важных для России инновационных проектов. Возрождение производства данной культуры способно обеспечить рабочими местами примерно один миллион граждан, ежегодный оборот отрасли может составить свыше 100 млрд. р., о чем свидетельствуют данные «Комитета торгово-промышленной палаты Российской Федерации».

Государство намерено расширять стимулирование активности сельхозпроизводителей в этом секторе производства, что позволяет в перспективе рассчитывать на отдельные льготы в сфере переработки конопляной культуры. Программа нацелена на то, что повсеместно будут строиться заводы по переработке сельскохозяйственного сырья. Тем самым, проблема сбыта будет решена, т.к. множество производств нуждается в разнообразной конопляной продукции. Это сделает выращивание технической конопли практически безотходным и высокорентабельным производством.

Рассматриваемая тема в последние годы освещается во многих зарубежных и отечественных работах, а также является предметом дискуссий на международных и региональных научно-практических конференциях. Систематизация и критический анализ материалов по тематике исследования проведены на основании работ известных ученых: В.К. Астанина, В.В. Богданова, И.А. Валеева, В.Н. Водякова, С.И. Вольфсона, И.В. Воскобойникова, В.В. Глухих, М.Л. Кербера, А.А. Клесова, Ю. Лонга, Р.Г. Мелконян, И.Н. Мусина, И.В. Скопинцева, В.А. Ушкова, И.3. Файзуллина, Н.И. Шубина и других [2, 3, 4, 5 и др.].

В работах [6] М.В.Шинкарук, М.В.Шамшуры, Т.О. Кузьмина; [7] В.А. Серкова, А.А. Смирнова, М.Р. Александрова и др. отражено современное состояние конопляной отрасли, а также рассматривается деятельность коноплеводов России.

Однако, несмотря на большое количество исследований в области биоразлагаемых материалов, воз- можности совершенствования их состава и технологий производства далеко не исчерпаны.

В настоящее время активно рассматриваются вопросы, связанные с проблемами и перспективами производства и утилизации биоразлагаемых материалов, в частности вопросы, связанные с обоснованием производства расходных материалов для сферы медицинских услуг из биоразлагаемого сырья, направленные на улучшение экологической ситуации в России, сложившейся в связи с COVID-19. Среди исследуемых видов сырья для медицинской, и других отраслей промышленности, хорошие характеристики показали лубяные культуры, например, растительное конопляное сырье, которое произрастает на территории России и неприхотливо к погодным условиям, в отличии от импортируемого льна.

Проведенные авторами исследования [8] экономической деятельности Тюменского региона, динамики объема розничного товарооборота, деятельности сельскохозяйственного сектора, позволили сделать вывод о том, что потенциал развития отслеживается на территории Юга Тюменской области.

Настоящее исследование направлено на подтверждение целесообразности проекта строительства завода по переработке конопли на территории Юга Тюменской области, подчеркивает ее народнохозяйственное значение и аргументировано необходимостью производства медицинского текстиля и картона в РФ. Успешному запуску должна послужить проработанная законодательная база для ведения производства, поддержка государственно-частного партнерства, а также, внедрение в производство усовершенствованной сельскохозяйственной техники для получения востребованной на потребительском рынке продукции.

Для решения поставленных задач использовались общенаучные методы познания (экономико-математического моделирования, элементы сценарного и системного подходов, методы статистической обработки получаемых результатов), методы статистического анализа и традиционные методы оценки эффективности инвестиций.

Возможности и преимущуества выращуивания технической конопли. Конопля является одной из самых древних выращиваемых человеком культур и активно использовалась во всем мире. В России данная культура была активно культивирована до конца XIX века, продукция экспортировалась в страны Европы и имела большой спрос благодаря своей прочности (парусина, корабельные веревки, канаты и др.). Данная 
Таблица 1. Сравнительный анализ урожайности соломы и годового выхода целлюлозы среди культур (с 1 га)

\begin{tabular}{|l|l|l|l|}
\multirow{2}{*}{ Культура } & Урожайность соломы, ц/га & Выход целлюлозы & Масса в год, т/га \\
\cline { 3 - 4 } & & Выход в\% & $1,1-2,2$ \\
\hline Лён-долгунец & $20-40$ & 54,0 & $2,1-4,3$ \\
\hline Рапс & $50-100$ & 42,5 & 7,0 \\
\hline Конопля & 135 & 52,0 & \\
\hline
\end{tabular}

Таблица 2. Положительные свойства технической конопли

\begin{tabular}{|c|c|c|c|}
\hline Неприхотливость & Качество ткани & Низкая себестоимость & $\begin{array}{l}\text { Экологичность, бактерицидные } \\
\text { свойства }\end{array}$ \\
\hline $\begin{array}{l}\text { Для выращивания, требуется } \\
\text { в несколько раз меньше воды, чем } \\
\text { для производства хлопка, }\end{array}$ & $\begin{array}{l}\text { Прочна, как лен, } \\
\text { но со временем } \\
\text { становится мягкой. }\end{array}$ & $\begin{array}{l}\text { Производство } \\
\text { конопляных тканей } \\
\text { в несколько раз дешевле } \\
\text { тканей из хлопка и льна. }\end{array}$ & $\begin{array}{l}\text { Материал из конопли на 100\% } \\
\text { разлагается в почве, обогащая ее } \\
\text { микроэлементами. }\end{array}$ \\
\hline $\begin{array}{l}\text { Один гектар конопли дает } \\
\text { в три раза больше сырья для } \\
\text { производства ткани, чем один } \\
\text { гектар хлопка или льна. } \\
\end{array}$ & $\begin{array}{l}\text { Ткань из конопли } \\
\text { прекрасно "дышит", } \\
\text { впитывает влагу. }\end{array}$ & & $\begin{array}{l}\text { Каннабидиол, содержащийся } \\
\text { в конопле эффективен в борьбе } \\
\text { с бактериями. }\end{array}$ \\
\hline $\begin{array}{l}\text { Не требует удобрений } \\
\text { и пестицидов, и не истощает почву, } \\
\text { как это делает хлопок (и даже } \\
\text { скорее обогащает ее). }\end{array}$ & $\begin{array}{l}\text { Конопляная ткань } \\
\text { не усаживается, } \\
\text { отлично держит форму, } \\
\text { окрашиваются лучше } \\
\text { хлопка. } \\
\end{array}$ & & $\begin{array}{l}\text { Во время роста конопля поглощает } \\
\text { сО2, генерируя для окружающей } \\
\text { среды кислород. }\end{array}$ \\
\hline $\begin{array}{l}\text { У технической конопли меньшее } \\
\text { количество вредителей } \\
\text { по сравнению с другими } \\
\text { культурами. }\end{array}$ & $\begin{array}{l}\text { Волокно из конопли } \\
\text { не гниет. }\end{array}$ & & $\begin{array}{l}\text { Содержание целлюлозы в конопле } \\
\text { доходит до 65\%. Таким образом, } 1 \text { га } \\
\text { конопли заменяет } 4 \text { га леса. }\end{array}$ \\
\hline
\end{tabular}

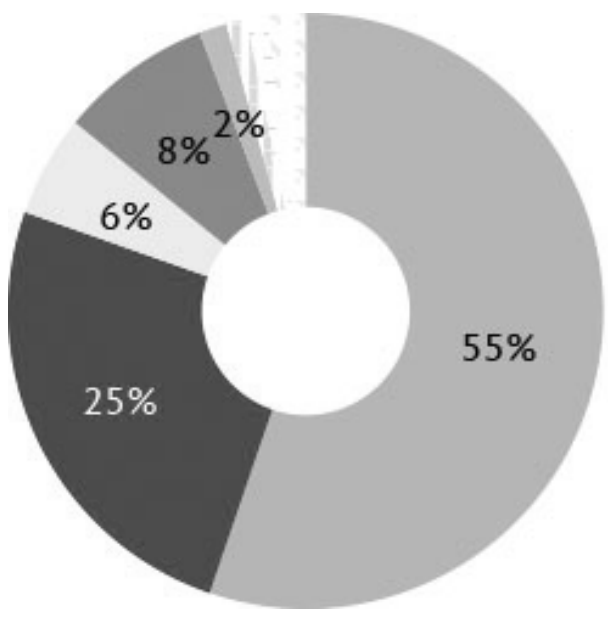

Китай

- Канада

Франция

ш почие страны ЕС

Россия

Украина

США

Прочие страны

Рис. 1. Структура мирового объема посевных площадей

культура дает урожайность соломы в 135 ц/га, годовой выход целлюлозы с одного гектара из конопли в 7 раз больше, чем с древесины (табл. 1).

Свое признание культура получила благодаря новым выведенным сортам. Содержание наркотических веществ в них сведены к менее 0,1\%. Преимущества данной культуры обозначены в таблице 2.

Спектр использования продуктов переработки конопли в мировой экономике стабильно расширяется, разрабатываются индустриальные технологии произ- 
водства изделий для применения в инновационных сферах промышленности. Конопля приобретает статус стратегической культуры, выращивание и переработка которой, являются приоритетными направлениями экономической политики многих развитых стран и инвестиций частного бизнеса.

По данным на 2014 г. в мире было произведено 78,3 тыс. т. конопляной пеньки и порядка 57 тыс. т. семян конопли. При этом лидером по производству семян является Франция, на долю которой пришлось 73\% мирового рынка, а в производстве пеньки лидерство делят Китай (28\%), КНДР (25\%) и Нидерланды (18\%).

В 2015 г. доля Китая составила порядка 55\%. Канада является второй страной в мире по объему выращивания конопли - более $25 \%$ (рис. 1) [9].

конопли, 2015 г., тыс. га

На данный момент традиционные товары, изготавливаемые на основе нефти, таких как полимеры, заменяют растительным сырьем, которое способствует переходу к рациональному потреблению ресурсов.

Вышеизложенная информация отражает актуальность и перспективы производства биоразлагаемых материалов на основе конопляного волокна.

Техническая конопля в производстве продукичии. За рубежом выпускается более 300 видов изделий из конопли, тогда как в России этот список уменьшился, в результате ратификации Конвенции $\mathrm{OOH}$ «O наркотических средствах», которая серьезно усложнила правила культивирования конопли. Советское государство пошло по линии наименьшего сопротивления, максимально сократив площадь посевов [10]. Сегодня, возрождаемыми видами продукции из конопли, в РФ являются: масло холодного отжима, мука, семена, утеплители, арболит, канатно-веревочные изделия, ткани, геотекстиль. Подписан указ о стратегии государственной антинаркотической политики РФ на период до 2030 года [11].

Возможность реализации производства продукции, обусловлена стратегией Социально-экономического развития Тюменской области до 2030 года [12].

На основе проведенного анализа сильных и слабых сторон, возможностей и угроз развития, выявлены положительные аспекты, благоприятные для данного проекта. Это выгодное географическое положение региона, высокий уровень предпринимательской инициативы; развитая система государственной поддержки предприятий, рост численности населения, из-за раз- витой инфраструктуры города; оказание высокотехнологичных видов медицинской помощи, развитое сельское хозяйство, строительный сектор.

Костра конопли, как отход производства после получения волокна, используется в целлюлозной промышленности.

Строительные материалы на основе конопли обладают исключительными тепловыми, характеристиками, которые снижают потребление энергии, обладают негорючими свойствами, а также устойчивостью к плесени и бактериям, способные естественным образом регулировать влажность.

При выборе выпускаемой продукции, есть основания полагать, что биоразлагаемая продукция из конопляного волокна будет востребована в медицинской и строительной отраслях, целлюлозной промышленности на территории Тюменской области. Предполагаемая продукция -медицинский текстиль из волокна конопли, картон, получаемый из костры.

Возможность выращчивания и производства биоразлагаемых материалов из конопли на территории Тюменской области. В коллективных трудах «Очерки истории Тюменской области» говорится о том, что первые посевы льна появились в крае в конце XVII века, а из технических культур крестьяне возделывали лен, коноплю, хмель и табак. Проведенные полевые исследования показали, что почвенно-климатические условия южной части Тюменской области являются благоприятными для возделывания конопли и льна, также упоминается, что в области, изготавливали конопляное и льняное масло. В одном из приложений к отчету сообщалось, что в Курганском уезде на десятину земли (1,09 га) высевалось от 4 до 6 пуд. семян льна и 4 пуд. (0,066 тонн) конопли. Планировалось повысить урожайность конопли до 5-6 ц/га в среднем. Осуществить задуманное помешала Великая Отечественная война [13].

В Тюмени с 1960 г. крупнейшее предприятие легкой промышленности - КСК «Кросно» (ТК Кросно) занималось производством всех типов товаров легкой промышленности по полному циклу - от приема сырья (сырая шерсть, хлопок, лен и др.) до готовых тканей и пошиву изделий из них, с возможностью выдачи продукции с любого этапа. Промышленная коллекция «Кросно» насчитывала около 300 тканей. С 2013 г. предприятие прекратило свое существование. Обобщая вышеизложенное, можно сделать вывод, что возделывание конопли на территории Тюменской области, актуально по сей день. Целесообразно наладить темпы производства продукции из данной культуры, о чем 
Таблица 3. Основные конкуренты на рынке производства продукции из конопли

\begin{tabular}{|c|c|c|c|}
\hline \multicolumn{2}{|l|}{ Компании зарубежные } & \multicolumn{2}{|l|}{ Российские компании } \\
\hline Компания & Продукция & Компания & Продукция \\
\hline Hemp Oil Canada & Масло, семена, протеин & Konoplex Group & Масло, текстиль \\
\hline $\begin{array}{l}\text { Литовский завод Natural } \\
\text { Fiber }\end{array}$ & $\begin{array}{l}\text { Конопляное волокно, пряжа, } \\
\text { гранулы биотоплива }\end{array}$ & «Экосфера» Нижнекамск & (товарные семена) технической конопли \\
\hline $\begin{array}{l}\text { Португальский завод } \\
\text { Tilray }\end{array}$ & Медицинские препараты & Smarthemp & Текстиль, картон \\
\hline Ecofibre & Косметические средства & $\begin{array}{l}\text { Агро-промышленная } \\
\text { ассоциация коноплеводов }\end{array}$ & $\begin{array}{l}\text { Объединяет представителей научно- } \\
\text { исследовательского корпуса, } \\
\text { возделывателей и переработчиков } \\
\text { конопляного сырья }\end{array}$ \\
\hline MH Medical Hemp & $\begin{array}{l}\text { Фармацевтика, косметические } \\
\text { средства }\end{array}$ & «Коноплектика» & Пищевое сырье \\
\hline Colorado Hemp Works & Пищевая продукция & $\begin{array}{l}\text { РГАУ-МСХА имени } \\
\text { К.А. Тимирязева }\end{array}$ & $\begin{array}{l}\text { Российский государственный аграрный } \\
\text { университет }\end{array}$ \\
\hline GenCanna & $\begin{array}{l}\text { Фармацевтика, масла, } \\
\text { косметические средства, } \\
\text { продукты питания }\end{array}$ & ООО «Экоконтроль» & $\begin{array}{l}\text { Научные исследования в области } \\
\text { технологии возделывания технической } \\
\text { конопли, переработки сырья } \\
\text { и утилизации отходов этих культур }\end{array}$ \\
\hline South Hemp Tecno & Мульча, 300 продукция & Мордовский пенькозавод & Строительство и автомобильная отрасль \\
\hline Hemp Poland & $\begin{array}{l}\text { Фармацевтика, косметика, } \\
\text { масла }\end{array}$ & Агрофирма «Южная» & Семена \\
\hline Plains Industrial Hemp & $\begin{array}{l}\text { Утеплитель, абсорбент, } 300 \\
\text { продукция, мульча } \\
\end{array}$ & Иркутск & Целюлоза \\
\hline Processing, Hempco & $\begin{array}{l}\text { Пищевые продукты, семена, } \\
\text { протеин }\end{array}$ & «ПромРуссКон» Курган & $\begin{array}{l}\text { Нано и микроцеллюлоза, бумага, } \\
\text { текстиль, композиты, биоразлагаемая } \\
\text { тара типа ПЭТ, биотопливо. }\end{array}$ \\
\hline BAFA & Фармацевтика & $\begin{array}{l}\text { «Нижегородские волокна } \\
\text { конопли» }\end{array}$ & Тканые и нетканые материалы \\
\hline Canah International & Пищевая продукция & & \\
\hline Hemp Inc. Dun Agro & $\begin{array}{l}\text { Фармацевтика, бетон, 3оо- } \\
\text { продукт }\end{array}$ & & \\
\hline
\end{tabular}

свидетельствуют данные «Комитета торгово-промышленной палаты Российской Федерации по развитию агропромышленного комплекса». Увеличение к 2030 г. площади посевов конопли до 1 млн. га, может дать около 3 трлн. руб. в ВВП. Увеличение доли инновационных продуктов - целлюлозы (в мире из 450 млн.т. доля целлюлозы из однолетних растений составляет $19 \%$ или 85,5 млн.т, в России — около 0\%) для углеродных нитей, биопластика, композитов, биологически активных веществ и др.

Конкурентная среда производства продукции. Основными конкурентами на рынке производства продукции из конопли являются как зарубежные компании, так и отечественный рынок, который набирает обороты и расширяется. Список основных конкурентов представлен в нижеследующей табл. 3.

В настоящее время на территории Тюменской области функционирует одно предприятие по выпуску гофрокартона ООО Завод «ГофропакТюмень», произво- дительностью 42 млн.м² в год. Сырьем служат закупаемые готовые рулоны картонной бумаги марок Т-24-Т-27 и П-31-П34. В Курганской области действует завод «Люксокрафт», производительностью 54 млн.т. в год. В качестве сырья используются первичные волокна, целлюлоза, вторичное бумажное сырье. Кроме того, функционируют небольшие предприятия, не производящие картон, а лишь продающие готовую продукцию: «А Мегапак», «Тюмень-ПАК», «Зима», «ФастМоверс72», «Упаковкаторг Тюмень» и др.

По результатам анализа рынка конкурентов, можно отметить сильные и слабые стороны проекта завода по выпуску биоразлагаемых материалов, представленные в SWOT анализе (табл. 4).

Среди сильных сторон - в первую очередь, свободная ниша в производстве медицинского текстиля и отсутствие конкуренции с другими видами сельскохозяйственных культур, выращиваемых в зоне резко-континентального сухого климата. 
Таблица 4. SWOT-анализ предприятия

\section{Сильные стороны (внутренние, положительные факторы)}

Слабые стороны (внутренние, негативные факторы)

- Отсутствие аналогов заводов по производству медицинского текстиля, позволяющего перейти на натуральный растительный материал, обладающий антисептическими, бактерицидными свойствами.

- Применяемое для производства сырье (костра конопли), позволит уменьшить вырубку леса для изготовления целлюлозы (конкуренты в г. Тюмень, используют древесную целлюлозу в производстве).

- Возможность увеличения рабочих мест.

- Перерабатывающая мощность завода позволит фермерам сбывать сырье конопли и увеличивать площади посевов.

- Увеличение объемов производства целлюлозы, в четыре раза больше, чем из деревьев с той же площади, только деревья растут 50 лет, а конопля вызревает за 110 дней.

- Процесс получения целлюлозы из конопли вдвое короче, чем из древесины, обходится без вредных выбросов в окружающую среду.

- Нет конкуренции с другими видами сельскохозяйственных культур, выращиваемых в зоне резко-континентального сухого климата.

\section{Возможности (внешние, положительные факторы)}

Угрозы (внешние, негативные факторы)

• Молодой рынок производства товаров из конопли, набирающий большую популярность.

- Увеличение площади посевов конопли до 1 млн. га, может дать около 3 трлн. руб. в ВВП.

- Увеличение доли инновационных продуктов.

- Государственно-частное партнерство позволит уменьшить затраты на капитальные вложения.

- Государственные программы поддержки сельхозпроизводителей - это возмещение части капитальных затрат, погектарная поддержка, поддержка элитного семеноводства, а также возможность подписания концессионных соглашений.

- Предполагается брать в переработку техническую коноплю, в том числе сторонних хозяйств, формируя, таким образом, в Тюменской и сопредельных областях отраслевой региональный кластер.

- Конопля способна заменить хлопок, который в России не растет и полностью импортируется. Рынок хлопкового волокна сегодня составляет порядка 50 тыс. т. в год.

- $\quad$ Производство по выпуску продукции из конопли, будет развивать не только сельское хозяйство, но и текстильную и строительную отрасли.

- Стимулирование развития машиностроения.

- Для запуска производства требуется импортное дорогостоящее оборудование для обработки конопли.

- Для того чтобы изготавливать продукцию из собственновыращенного сырья, необходимы значительные затраты в усовершенствованную сельскохозяйственную технику, а также большие площади сельскохозяйственных угодий.

- Отсутствие отечественного опыта
.
Рехнологий при производстве.
из-за общего технологического
отставания не сможет работать
с таким сырьем.
Для внедрения новой ткани
в медицинскю отрасль,
необходимо внесение в ГОст
и другие нормативные документы
разрешение использования
волокна конопли для
производства медицинских
материалов.

Конкурентом по выпуску картона является ООО Завод «ГофропакТюмень». Однако, в качестве сырья, на заводе используется покупная картонная бумага. Соответственно, преимуществом перед конкурентом, является применяемое для производства сырье - костра конопли, которая позволит уменьшить вырубку леса для изготовления целлюлозы

Возможность сотрудничества в форме государственно-частного партнерства. В целях реализации проекта, рассмотрены меры государственной поддержки; субсидирование затрат на приобретение семян конопли, минеральных удобрений, соответствующей техники; соглашение о государственно-частном партнерстве. Минпромторг поддерживает легкую промышленность в рамках Госпрограммы развития промышленности и повышения ее конкурентоспособности: субсидирование на культивацию 10тыс. руб на 1 га.; субсидирование элитных семян, 1,2 репродукции; ввозная пошлина на зарубежное оборудование, 0\% НДС.

При сотрудничестве с государством, допустимо подписание концессионного соглашения. Одним из таких проектов в России, стал завод ГК «Коноплекс», строительство которого осуществляется в Пензенской области на условиях концессии [9]. 
Таблица 5. Прогноз потребности в пеньковолокне

\begin{tabular}{|c|c|c|c|c|c|c|}
\hline \multirow[b]{2}{*}{ Наименование } & \multicolumn{3}{|c|}{ Ткани (млн. м2) } & \multicolumn{2}{|l|}{ Вата (тыс. т.) } & \multirow{2}{*}{$\begin{array}{l}\text { Стройка (тыс. т.) } \\
\text { Объемный } \\
\text { утеплитель }\end{array}$} \\
\hline & $\begin{array}{l}\text { Бельевые } \\
\text { (140 гр/м2) }\end{array}$ & \begin{tabular}{|l|} 
Костюмные \\
(250 гр/м2)
\end{tabular} & $\begin{array}{l}\text { Брезенты } \\
\text { (450 гр/м2) }\end{array}$ & $\begin{array}{l}\text { Индивидуальный } \\
\text { перевязочный пакет }\end{array}$ & Перевязка & \\
\hline Миобороны РФ & 30 & 9 & 9 & 30 & 5 & \\
\hline МВД РФ & 30 & 9 & 3 & - & 2 & \\
\hline Минздрав РФ & 21 & - & - & - & 10 & \\
\hline Минтранс РФ & 700 & 20 & 3 & - & - & \\
\hline $\begin{array}{l}\text { Гражданское } \\
\text { направление }\end{array}$ & 30 & - & - & - & 15 & 60 \\
\hline ИТОГО & 811 & 38 & 15 & 30 & 32 & 60 \\
\hline $\begin{array}{l}\text { В пересчете } \\
\text { на волокно, тыс. т. }\end{array}$ & 162,3 & 13,6 & 9,6 & 46,1 & 49,2 & 70,6 \\
\hline ВСЕГО, тыс. Т. & \multicolumn{2}{|l|}{175,9} & 9,6 & \multicolumn{2}{|l|}{95,3} & 70,6 \\
\hline ИТОГО тыс. т. & \multicolumn{6}{|l|}{351,4} \\
\hline
\end{tabular}

Необходимость правок законодательства для развития рассматриваемой производственной сферы. Отличительной особенностью проекта, является производство медицинского волокна, используемого в медицинских учреждениях, в салонах красоты, в быту из натурального конопляного волокна. В данный момент, разрешено безлицензионное выращивание и использование сортов агропромышленной конопли, включенных в Государственный Реестр селекционных достижений и допущенных к использованию в Российской Федерации. Семена должны быть сертифицированы.

Планируется сотрудничество с текстильными предприятиями области для отработки технологии добавления конопли в хлопчатобумажные ткани, которые в результате получат новые антисептические, бактерицидные свойства и станут более долговечными. Необходимым условием внедрения новой ткани в медицинскую отрасль является утверждение поправок, на разрешение внесения данного волокна конопли в список разрешенного сырья для производства медицинских расходных материалов.

В медицинской сфере применяются одноразовые ткани из синтетического волокна, в соответствии с ГОСТ Р 58551-2019 национальный стандарт Российской Федерации «Изделия медицинские одноразовые из нетканых материалов. Одежда и белье хирургические одноразовые из нетканых материалов» [14]. Нормативный документ ГОСТ Р 58551-2019 не рассматривается конопляное волокно, также, как и ГОСТ 24760-81 «Халаты медицинские женские»: ткань хлопчатобумажная - ткань, вырабатываемая из пряжи, содержащей $100 \%$ хлопкового волокна или хлопкового волокна с вложением не более $10 \%$ вискозного или вискозного высокомодульного волокон; ткань смешанная - ткань, вырабатываемая из пряжи, содержащей хлопковое волокно с вложением не более 50\% химических волокон или нитей [15].

Следует внести поправку на применение конопляного волокна в ГОСТ 7000-80 «Материалы текстильные. Упаковка, маркировка, транспортирование и хранение», с соблюдением требований к медицинскому волокну и лабораторным исследованиям [16].

Технико-экономические показатели на основе объектов-аналогов. Проектом предусматривается: завод по производству и утилизации биоразлагаемых материалов в Тюменской области, в который входят: цех по производству биоразлагаемых материалов в текстильном секторе (примерный ассортимент: медицинский текстиль); цех по производству биоразлагаемых материалов в строительном секторе (стеновые блоки, утеплитель, канаты, шпагат и пр; цех по утилизации биоразлагаемых материалов методом компостирования.

Обоснование определения мощности объекта оценивается на основе проектов-аналогов: завод на территории Ивановской области компании «Smarthemp»; завод «Tilray» (Португалия); завода по переработке стеблей волокнистой конопли «Natural Fiber» (Литва).

По информации департамента растениеводства Минсельхоза России, прирост потребности в лубяных культурах с 2016 г. по 2020 г., составил 5,4\%, а на основе данных Минпромторга России в среднем составил 2,2\%. В начале 1990 г. в России действовало 75 пенькозаводов, к 2016 году функционировало лишь 6 пенькозаводов, что говорит о регрессе посевных площадей под 
Таблица 6. Основные технико-экономические показатели

\begin{tabular}{|c|c|c|}
\hline 1. & Площадь земельного участка & 1,8 гектар. \\
\hline 2. & Площадь производственного комплекса & 5 тыс. КВ. м. \\
\hline \multirow{2}{*}{3.} & \multirow{2}{*}{ Мощность завода } & 20 тыс. тонн стеблей конопли в год \\
\hline & & 7 тыс. тонн конопляного волокна \\
\hline 4. & Количество рабочих мест & 10 чел. \\
\hline 5. & Капитальные вложения & 2 млрд. руб. \\
\hline 5.1 & Затраты на закупку сельскохозяйственной техники & 700 млн. руб. \\
\hline 5.2 & Строительно-монтажные работы & 500млн. руб. \\
\hline 5.3 & Затраты на покупку оборудования & 800 млн. руб. \\
\hline \multirow[t]{2}{*}{6.} & Операционные расходы & 500 млн. руб. \\
\hline & Итого инвестиции в проект & 2,5 млрд. руб. \\
\hline
\end{tabular}

Таблица 7. Основные экономические показатели выращивания и переработки 1 га конопли (семена, волокно)

\begin{tabular}{|l|l|}
\hline Наименование & Показатель \\
\hline Затраты на выращивание и переработку 1 га конопли (семена и волокно), рублей & 55034,0 \\
\hline Реализация волокна с 1 га конопли, рублей & 32000,0 \\
\hline Реализация костры с 1 га конопли, рублей & 14400,0 \\
\hline Реализация семян с 1 га конопли, рублей & 63000,0 \\
\hline Реализация всего, рублей & 109400,0 \\
\hline Рентабельность,\% & 98,8 \\
\hline
\end{tabular}

Таблица 8. Предварительные затраты на выращивание конопли

\begin{tabular}{|c|c|c|}
\hline \multicolumn{3}{|c|}{ Предварительные затраты на выращивание конопли } \\
\hline 1. & Закуп семян с доставкой & 12000000 рублей. \\
\hline 2. & Сельскохозяйственное оборудование & 700000000 рублей. \\
\hline 3. & Аренда, покупка земельного участка & 5000000 рублей. \\
\hline 4. & Строительство теплиц & 3000000 рублей. \\
\hline 5. & Тепло-водо-электроэнергия & 7000000 рублей. \\
\hline 6. & ФОT & 550000 рублей. \\
\hline 7. & Лабораторные исследования & 350000 рублей \\
\hline \multicolumn{2}{|c|}{ Итого: } & 727900000 рублей. \\
\hline
\end{tabular}

коноплю [17]. По прогнозу потребности в пеньковолокне с учетом госзаказа, объемы требуемой текстильной продукции для всех государственных структур превышают 175 тыс. тонн., на медицинские цели требуется порядка 95,3 тыс. тонн. волокна, на строительство необходимо 70,6 тыс. тонн волокна [18] (табл. 5).

Потребность Тюменского региона - 20 тысяч тонн технической конопли в год. Это соответствует площади посевов 1,8 гектар.

Конопляное производство является высоко рентабельным, безотходным, поскольку различные составляющие этой культуры идут на различные виды продукции.
Для выращивания конопли требуются большие капиталовложения и текущие затраты (см. табл. 8).

«Плюсы» производства - увеличение прибыли с различного ассортимента продукции, собственное сырье, контроль за качеством семян, прибыль с продаж, обогащение почвы питательными веществами, увеличение урожайности других культур, поглощение $\mathrm{CO}_{2}$.

«Минусы» производства - на первых этапах, большие затраты на выращивание, риск плохого урожая.

Таким образом, на начальном этапе, следует закупать готовое сырье и апробировать производство 
продукции. В дальнейшем, после запуска проекта в Тюменской области, анализа доходности и окупаемости проекта, целесообразно, выращивание уже собственного сырья и расширение производства с другими видами продукции (строительные материалы (утеплитель, костробетон), мебель из МДФ и ДСП), следовательно, далее необходимо рассмотреть оборудование для переработки культуры.

Механизмы и оборудование для переработки конопли. На рынке появляются новые перспективные технологии по первичной переработке конопляной тресты, технологии котонизации и прядения конопляного волокна.

Производство конопляного, волокна начинается с декортикации тресты, в результате чего образуется конопляная костра и конопляное волокно [10].

Процесс начинается с грубой очистки от камней, после чего начинается процесс декортикации тресты. Технологическая цепочка является продолжением линии производства волокна из соломы или тресты, основанной на технологии декортикации, обеспыливания, очистки и утончении волокна.

Линия состоит из технологических модулей: нарезки волокна, очистки, разволокнения на элементарные волокна, второй очистки и кипования.

Для получения качественного волокна из сырья необходимы правильный процесс мацерации и достаточная прочность на разрыв исходного сырья. При этом технологическим ядром линии котонизации выступает модуль с двумя барабанными котонизаторами (технология котонизации «LAROCHE»). Технология сложная и длительная, но позволяющая полностью исключить химическую обработку сырья, не требуя замачивания и сушки, что снижает себестоимость продукции. Кроме того, данная технология дает возможность получать смесовую пряжу по технологии шерсти и хлопка. Это важно, так как конопляную пряжу делали на мокропрядильных линиях, которых сейчас не осталось. По данной технологии также можно котонизировать лён.

Преимущества технологической линии «LAROCHE» по сравнению с технологиями компании «Hammer mills» и компании «Duvex»: высокая прочность получаемого волокна, увеличенный выход волокна на 20-30\%, экономия электроэнергии; низкая стоимость обслуживания, меньшее количество пыли [19].

Действительно полное разложение полимеров, по свидетельству независимых экспертиз, возможно только в случае их изготовления из растительного сырья, в частности, конопляного волокна.

В последние 8-10 лет в мировой экономике происходит динамичное увеличение производства конопли. Разностороннее использование семян, волокна, костры, возможность получать хорошие урожаи без пестицидов, вполне подтверждают её огромное народнохозяйственное значение. Конопля обладает рядом преимуществ перед другими культурами, являясь безотходной.

Практически любой продукт, который может быть изготовлен из дерева, хлопка или нефти (включая пластик), могут быть произведены из конопли. Конопля может заменить все другие виды тканей без применения химических веществ. В настоящее время в мире существует устойчивая тенденция замены синтетических материалов натуральными.

Но существует ряд проблем в области выращивания конопли: устаревшая материально-техническая база (отсутствие современной уборочной техники); сокращение семеноводческих предприятий и хозяйств, ведущих семеноводство и районирование новых сортов; слабо оснащённые лаборатории, дефицит кадров.

В области переработки конопли: износ основных фондов; устаревшая материально-техническая база; нарушение технологии (отсутствие современных сушильных комплексов и перерабатывающего оборудования).

В области текстильного производства: медленное техперевооружение производств (устаревающая техническая и технологическая оснащенность, отсутствие машиностроения по изготовлению прядильного, ткацкого и отделочного оборудования); низкий уровень господдержки.

Необходимо ускорение инициирования программы, направленной на возрождение отечественного коноплеводства, а также налаживание производства принципиально новых высокопроизводительных сельскохозяйственных машин и оборудования по переработке лубяных культур.

Сегодня наша планета задыхается от свалок, леса безответственно и массово вырубаются. Загрязнение воздуха, яды и химикаты вызывают онкологические заболевания. В решение этих проблем определенный вклад может внести выращивание промышленной конопли, способствующее сохранению окружающей среды и повышению эффективности отечественной экономики. 


\section{ЛИТЕРАТУРА}

1. Ассоциация организаций, операторов и специалистов в сфере обращения с отходами «Чистая Страна»: [сайт]. — URL: https://cleancountry.ru (дата обращения: 10.03.2020).— Текст: электронный.

2. Астанин, В.К. Информационная система учета отходов производства на предприятиях АПК / В.К. Астанин, Е.В. Пухов, И.С. Волронков // Техника в сельском хозяйстве. - 2012.— № 4.-31-32 с.

3. Лонг, Ю. Биоразлагаемые смеси и композитные из возобновляемых источников / Ю. Лонг // Изд — во «НОТ».— 2013.

4. Кербер, М.Л. Полимерные композиционные материалы: структура, свойства, технология: учеб. Пособие / М.Л. Кербер, В.М. Виноградов, Г.С. Головкин и др.; под ред. А.А. Берлина. СПб,: Профессия, 2008. - 560 с.

5. Dautova, A. Feasibility Study of Biodegradation of Polyamide-6 and Natural Rubber Composite Materials / A. Dautova, V. Yanova, N. Mingaleev, L. Zenitova // International journal of environmental \& science education, 2016. - V.11. — № 18. — PP. 12121-12130.

6. Шинкарук... Модификация конопляного волокна. ВІСНИК ХНТУ № 4(67), 2018р. С. 226-231

7. Смирнов А.А. К вопросу общей концепции инновационного развития отечественного коноплеводства / А.А. Смирнов, В.А. Серков, 0.Н. Зеленина // Достижения науки и техники АПК. — 2011. — № 12.— С. 34-36.

8. Скворцова Н.К., Валиуллина Е.Р., Минваева М. «Производство и утилизация биоразлагаемых материалов: проблемы и перспективы» «Водные ресурсы — основа глобальных и региональных проектов обустройства России, Сибири и Арктики в XXI веке».— 2021; сборник статей Национальной с международным участием научно-практической конференции.

9. Коноплекс: Сайт компании: [сайт]. — URL: http://konoplex.ru/ (дата обращения: 10.04.2020).— Текст: электронный.

10. Росленконопля: информационно-образовательный Интернет-ресурс: [сайт].— URL: https://www.rosflaxhemp.ru/ (дата 0бращения: 20.03.2021).— Текст: электронный.

11. «0 наркотических средствах и психотропных веществах»: Федеральный закон № 3-Ф3: Принят Государственной Думой 10 декабря 1997 года: Одобрен Советом Федерации 24 декабря 1997 года: [сайт]._— URL: http://www.consultant.ru/document/cons_doc_LAW_17437/ — Текст: электронный.

12. «06 утверждении Стратегии государственной антинаркотической политики Российской Федерации на период до 2030 года»: Указ президента Российской Федерации: 0т 23.10.2020 года N733: [сайт].— URL: https://docs.cntd.ru/document/566387046 — Текст: электронный.

13. «0б утверждении стратегии социально-экономического развития Тюменской области до 2030 года.»: Закон Тюменской области: Принят областной Думой 12.03.2020 года N23: [сайт].— URL: https://docs.cntd.ru/document/570710699 — Текст: электронный.

14. ГОСТ Р 58551-2019. Изделия медицинские одноразовые из нетканых материалов. Одежда и белье хирургические одноразовые из нетканых материалов: Национальный стандарт Российской Федерации: утвержден и введен в действие Приказом Федерального агентства по техническому регулированию и метрологии от 24 сентября 2019 г. № 741-ст: Дата введения 2020-05-01 / Разработан 0бществом с ограниченной ответственностью «Центр сертификации и декларирования» (000 «ЦСД») и Ассоциацией производителей медицинских изделий «Здравмедтех» (Ассоциация «Здравмедтех»): [сайт].— URL: https://docs.cntd.ru/document/1200167885/ — Текст: электронный.

15. ГОСТ 24760-81. Халаты медицинские женские: Государственный стандарт Союза ССР: утвержден и введен в действие Постановлением Государственного комитета СССР по стандартам от 18.05.81 № 2429/ разработан и внесен Центральным Правлением Всероссийского ордена «Знак Почета» 0бществом глухих: [сайт].— URL: https://docs.cntd.ru/document/1200019647 — Текст: электронный.

16. ГоСТ 7000-80. Материалы текстильные. Упаковка, маркировка, транспортирование и хранение: межгосударственный стандарт: утвержден и введен в действие Постановлением Государственного комитета СССР по стандартам от 09.12.80 № 9293: Дата введения 1981-07-01 / разработан и внесен Госкомлегпромом при Госплане CCCP: [сайт].— URL: https://docs.cntd.ru/document/901711455 — Текст: электронный.

17. Дом конопли: Маркетплейс товаров из технической конопли: [сайт]. — URL: https://domkonopli.ru/(дата обращения: 11.04.2020). — Текст: электронный.

18. Коноплеводство России 2017: перспективы культуры в возделывании и переработке: 000 «Издательство Листерра»: [сайт]. — URL: https://www. agroxxi.ru/blogs/konopelka/konoplevodstvo-rossii-2017-perspektivy-kultury-v-vozdelyvanii-i-pererabotke.html (дата обращения: 11.02.2021).— Teкст: электронный.

19. Laroche: Сайт производителя: [сайт].— URL: http://www.laroche.fr/ru/domaines-dactivites/\%D0\%BD\%D0\%B0\%D1\%82\%D1\%83\%D1\%80\%D0\%B0\% D0\%BB\%D1\%8C\%D0\%BD\%D1\%8B\%D0\%B5-\%D0\%B2\%D0\%BE\%D0\%BB\%D0\%BE\%D0\%BA\%D0\%BD\%D0\%B0.html (дата обращения: 12.04.2021).— Текст: электронный.

( С Скворцова Надежда Константиновна ( skvortsovank@tyuiu.ru ), Матыс Елена Геннадьевна ( matyseg@tyuiu.ru ), Филимонова Лариса Акрамовна ( filimonovala@tyuiu.ru ), Валиуллина Елена Робертовна ( valiullina.lena@inbox.ru ).

Журнал «Современная наука: актуальные проблемы теории и практики» 